Preliminary communication

Received: 1 May 2021

Dorijana Škoro, mag. mus.

Accepted: 20 September 2021

OŠ Mate Lovraka

Ul. Alojzija Stepinca, Županja

dorijanaskoro@gmail.com

https://orcid.org/0000-0003-2531-7656

Ivona Kir, mag. mus.

GŠ Josipa Runjanina

Ul. Hansa Dietricha Genschera 16E, Vinkovci

ivona.kir034@gmail.com

\title{
THE APPLICATION OF DIGITAL TOOLS IN LISTENING TO MUSIC IN MUSIC CULTURE EDUCATION
}

\begin{abstract}
Listening to music is a dominant activity in the Music Culture teaching in which students develop critical thinking about aesthetic value of music. Teachers mostly use CDs and DVDs as important tools during the music listening activity despite the development of technology. On today's classes we meet digitally literate students born in a completely digitalized world, which represents a great challenge for teachers. The students and the system expect a wide range of digital contents - audio tracks, videos, animations, photos, etc. Fortunately, teachers can choose digital tools which will be used for improvement of the teaching activity - music listening. Research has been conducted within this paper and its aim is to determine the way in which the teachers implement the music listening activity, as well as the influence of the use of digital tools that help the students with learning and motivation. 675 students from four general education schools from fifth to eighth grade and their teachers of Music Culture from Osijek-Baranya County, as well as Vukovar-Srijem County took part in this research. The research is experimental and it is divided into two phases - before and after the use of digital tools. The research results show that the digital tool Kahoot! helps students to learn the matter easily and that they are much more motivated during music listening. Also, both students and teachers have developed digital competences.
\end{abstract}

Key words: competences, digital tools, music culture, music listening 


\section{INTRODUCTION}

Teaching Music Culture in Croatia has had varied primary areas depending on the needs of the system, school and society. Historically, there have been several conceptual models: an active music making, a receptiveness, an integration (closed) and a combined (open) model. Due to the effects of those models and programmes, the main educational field and teaching methods for Music Culture changed as well, while each new model applied or reform carried out provided teachers with a growing autonomy in conceptualising programmes and lessons (Rojko 2012, Svalina 2015).

Music class is not a privilege of musically talented children, it is intended for the entire school population. It represents a planned influence on children's personality formation, awaking interest, needs, capabilities and an aesthetic relationship towards music in them. (Dobrota, 2016, p. 1)

Teaching Music Culture in general education emphasises the contact of student and music, while verbal information stems from music. Which is why listening to music has a central place in teaching nowadays. The objective of listening is to enable direct contact of student and music through high quality audio and video files. Sims (1990) points to the fact that selected musical examples should be reproduced via high quality devices, which the continued development of technology also enables. Apart from high quality equipment, she considers the choice of pieces as important, the length of which should also be appropriate for the students' age. Although the open model offers a degree of free choice regarding content in the education system, teachers encounter difficulties approaching and choosing said content, as well as finding high quality musical examples. (Nastavni plan i program za osnovnu školu 2006, NOK 2010)

Milinović (2018) explains that music has become more available than ever before thanks to the modernisation of technology. Students and teachers alike are not only able to access most of the audio content through various electronic devices, but reproduce them as well.

Vidulin and Martinović (2015) explain that listening to music and enabling students' contact with valuable works of art is no easy feat. They describe listening as an activity as a slow, gradual and protracted process, that should be carefully pedagogically, didactically and methodologically designed as well as clearly structured and precisely guided. Well prepared and guided, it serves students as an indispensable way of getting acquainted with artistic and folk music as well as other popular music genres that provide insight into global and national musical culture. Apart from musical taste, this approach helps form students' cultural identity as well. 
How to motivate students to listen to music actively? One should not talk about the music before listening, the music should have a chance to speak for itself. (Šulentić Begić \& Birtić, 2012, p. 5)

Rojko (2012) considers channelling students' attention towards active listening by posing questions about the musical elements, performers, musical form, tempo, melody, rhythm or dynamic just before listening to the piece. Repeated active listening, instead of passive listening, should be implemented through proper methodical procedures.

Passive listening doesn't put focus on the music. It becomes a circumstantial addition to other activities. That way of listening is often found in daily life (while driving, in shopping malls or at home) and it is often described in literature as inattentive music listening. That approach should be avoided, because only by listening actively do students gather knowledge about elements of musical expression, various organisational levels of musical pieces and learn to understand, evaluate and research new music. (Rojko 2012, Škojo 2010)

\section{THE MODERN SCHOOL}

The historical overview of the evolution of schools shows that needs and developments in society led to a new school taking the place the old one's place, while the new is being replaced by the modern.

The modern school should be continually developing and changing, just like the teacher, whose active being is the one perpetuating the change, so that new generations might be prepared for the insecurities of post-modern times. (Stoil and Fink 2000, as cited in Mlinarević and Borić, 2007, p. 422).

The modern school regards the student as the key to teaching and the reason for organising and designing the educational process. Matijević and Topolovčan (2017) explain that modern education is based on communication between teachers and students, the fundamental subjects of the educational process. They cooperate, striving to create cognitive, affective and psychomotorical objectives as well as tasks of such education (representation of modern education via didactic triangle in Figure 1).

The modern school changes the teacher's role form a lecturer, as per traditional education, into an organiser, leader, mentor and partner. (Zrilić and Marin 2019, p. 389)

Along with objectives and tasks, they explain the fact that the student is the one under the influence of the teacher to become an important factor in the educational process through learning and lessons. Matijević and Toplovčan (2017) also explain that a permanent exchange of positions between teacher and student, depending on the current topic, is a characteristic of the modern school. 
Tomorrow's school is not just a facilitator of different educational programmes, it is foremost an organiser, instigator and coordinator of their realisation. (Puževski, 2002, p. 121)

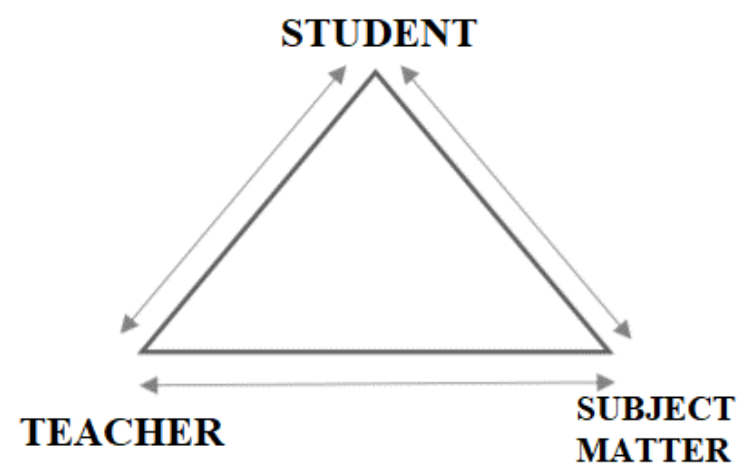

Figure 1. The modern school's didactic triangle (Puljak 1990, per Vurušić 2019, page 4. Source file://C:/Users/Korisnik/Downloads/vurusic_m_0069051027.pdf)

Poljak (1990) explains that expeditious technological development is one of the key elements to influence the expansion of the didactic triangle into a didactic rectangle (representation of modern education via didactic rectangle in Figure 2). The rectangle has a new element - technology - which coalesces with the previously established elements. Thanks to this addition, technology becomes an indispensable part of the education process, broadens educational horizons by giving students insight into elements impossible to see or experience directly.

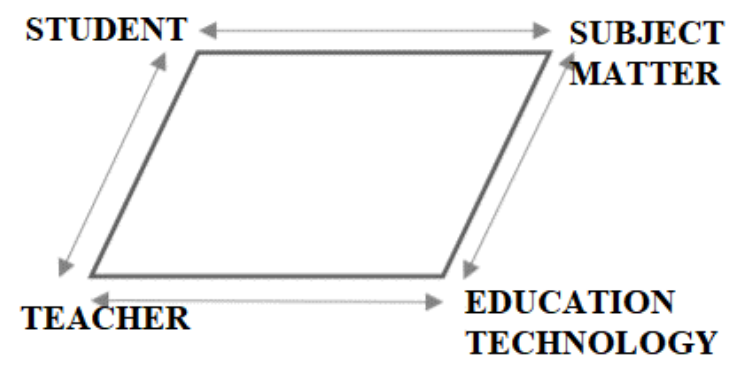

Figure 2. Didactic rectangle (Poljak 1990, as cited in Vurušić, 2019, p. 4. Source file://C:/Users/Korisnik/Downloads/vurusic_m_0069051027.pdf) 


\section{MODERN TECHNOLOGY IN EDUCATION - YES, OR NO?}

The prerequisites of multimedia education are being met by introducing modern technology into the education process. Bognar and Matijević (2005, as cited in Matijević \& Topolovčan, 2017) define multimedia education as using two or more different mediums in lessons, along with appropriate learning strategies. Such education encompasses digital media, e. g. smartphones, tablets, computers and laptops, as well as any accompanying digital tool. Due to the use of digital media in education, learning and teaching processes are not so strictly tied to school, but happen outside of it as well (at home, in the park, on a trip, with friends). This approach enables an interesting connection between extracurricular content and the education process, which is also an objective of the modern school.

"It is a great advantage to be able to store enormous amounts of data in a virtual memory mostly invisible to the naked eye. Moreover, digital data may be easily and swiftly processed, created and changed, while multimedia provides various possibilities of impressive (dynamic) presentation and simulation without danger of injury or material damage. Furthermore, if there is any logical connection, the computer can recognise and apply it, which ensures a simple analysis, synthesis, isolation (of elements) or emphasis." (Novosel, 2017, p. 66)

March (2006) explains that students may learn what they wish, when they wish and where they wish, thanks to digital media. Accordingly, we may come to the conclusion that the use of modern technology and digital media in education is very advisable. Students may use the aforementioned media and various materials they have access to daily from a young school age to learn independently. This leads us to questions about the process of self-education. Is it possible to implement self-education in Music Culture education and Can students of a younger and older school age learn Music Culture subject matter successfully with digital tools and media? It should be noted that teachers should, apart from using modern technology and media in lessons, continually research, systematise and explain materials, as well as be ready to teach such lessons that would ensure the best efficiency of the learning process. (Matijević \& Topolovčan, 2017)

\section{DIGITAL TECHNOLOGY AND TOOLS}

Just like technological progress and development impact society and the environment, they have visible effects on the general education process. Using digital media has become more frequent in the education process because of the various digital tools imposed on teachers daily that also offer an abundance of different activities to enhance the education process. Technological skills and affinity are results of maturing in a technologically saturated environment 
in which technological devices like computers, mobile phones and screens in general - are becoming a part of living. (Lasić-Lazić, Špiranec, \& Banek, 2012)

The handbook Digitalne tehnologije kao potpora praćenju $i$ vrednovanju ("Digital technology as an aid in monitoring and evaluating"), published 2018, states that using digital technology in the education process increases student motivation and concentration. Technology and tools also stimulate their independence and activity, attain educational objectives, tasks, outcomes and elements. Using digital tools provides teachers with a different and more innovative way of preparing for lessons and, if they so wish, they may use digital tools in the process of (self-)monitoring and (self-)evaluating education, personal work and progress, as well as students' progress. Present research shows that evaluating students' achievements is one of the most important, most sensitive and challenging areas of teaching. Digital technology enables teachers to actively include students into the monitoring and evaluation of their own progress. The students then have better control over their own learning and knowledge, and assume responsibility for it.

Seeing as all children do not learn in the same way, introducing educational technology into music education provides different possibilities for learning and helps the student develop creative thinking, problem solving, communication and team work. ((Dobrota, 2015, p. 4)

The advantages of using digital tools in education have led to the idea of using digital tools in Music Culture, specifically for listening to music. The principle of this activity hasn't changed in decades, it being performed by giving appropriate assignments to students to enable their active listening to music before listening to the musical piece multiple times. Answers are marked in music books or notebooks, and teachers note selected students' answers onto the blackboard or presents them on a projection screen by using a projector and computer program. (Svalina, 2105, as cited in Dobrota, 2012) The same procedure may be used in some of the digital tools, making it more interesting and effective. Kahoot! was used for the purposes of this paper.

\section{KAHOOT!}

Kahoot! is an interactive digital freeware tool designed for fast and simple test/quiz, questionnaire and discussion preparation. It was first published online in March 2013 and quickly became a favourite digital tool for both students and teachers. Kahoot! is available via the following link https://kahoot.it/. (Groznik 2021, Tomaš 2018)

Using digital tools in working with students has its own technical prerequisites, such as a computer and projector, as well as personal computers, laptops, tablets or mobile devices for students. The questions are displayed to the students via projector for at least 5 seconds, after which the screen shows 
multiple alternative answers along with a countdown. The questions may be closed-ended with two or more possible answers, or the validity of a claim may be determined. The question's concept may consist of text only, pictures or photographs, and newer versions of the tool enable embedding YouTube audio files. This option of incorporating a musical piece into quizzes has led to the idea of advancing the listening process in music education. (Negulić, 2015)

In its beginning stages of development, the tool didn't display questions or answer texts, just four different coloured shapes on the students' screens as depicted. Due to continued development of the tool, students today can see the questions and answers in appropriate different colours while answering. Students may not control the activity flow or skip questions in Kahoot! on their devices. Another advantage of the tool is that only a teacher may toggle whether questions are switched automatically or manually.

The 2018 handbook Digitalne tehnologije kao potpora praćenju $i$ vrednovanju explains that Kahoot! fosters competitiveness in students and encompasses real-time play elements in regards to monitoring and evaluating students' results. Thus, the authors of the handbook recommend using the tool as part of motivational lesson segments. The positive effects of the tool in regards to students' motivation are verified by the research of Nikolić, Lolić, Havzi, Spasojević and Stefanović (2021), which explores the effects of Kahoot! on students' motivation at the Faculty of Technical Sciences, Novi Sad, Serbia. $81.4 \%$ of students report the tool having a positive influence on their personal motivation, while $18.6 \%$ of students do not agree with that statement.

Research carried out in the Sesvete Gymnasium in 2018 in German language education (Kondres, 2018) shows that students using modern technology achieve greater progress than the control group using traditional means to learn. The experimental group achieved up to $24.92 \%$ better results in regards to the first test, as opposed to the control group, which showed a lower progress rate of $9.12 \%$.

As a drawback of the tool, the authors of the 2018 handbook mention that long-term monitoring of students' progress in not accessible. Students' results are displayed after each question; how many students have chosen which answer and final rankings showing five students with the most points at the end of the activity. After the activity, the tool offers the teacher to save students' results in an Excel sheet displaying their correct and incorrect answers. Newer versions of Kahoot! also warn teachers of questions that have lower correct answer rates and the ones with the most correct answers, providing the teacher with automatic feedback on how much of the material covered in the quiz was absorbed. 


\section{RESEARCH GOALS AND HYPOTHESIS}

The goal of this research is to investigate the importance of listening to music in Music Culture education, determine the way teachers implement listening to music, students' attitude towards music they encounter in Music Culture education, and whether students may be motivated to listen more actively by using a digital tool.

In accordance with the above goals of the research, the following hypothesis' are proposed:

H1: Students enjoy listening to music.

H2: Students do not listen to music they encounter in Music Culture education at home.

H3: Music Culture teachers often use digital tools in their lessons.

H4: Music Culture teachers consider listening to music one of the most important parts of their lessons.

H5: Students participate in Music Culture lessons more actively when using digital tools.

H6: Students listen to music more actively when using digital tools.

H7: Teachers educate themselves independently on using digital tools.

The tasks of the first students research stage were the following:

1. Determine students' attitude towards listening to music in Music Culture lessons.

2. Determine their attitude towards using digital tools while encountering music.

The tasks of the first teachers research stage were the following:

1. Determine the importance of the educational field of listening to music in Music Culture.

2. Determine the frequency and way of listening to music.

3. Determine digital competences in preparation for the second stage.

The tasks of the second students research stage were the following:

1. Determine the impact of digital tools on their motivation to listen to music more actively.

2. Determine the impact of digital tools on their motivation to participate in the education process more actively.

3. Determine students' attitude towards more frequent use of digital tools while encountering music.

The tasks of the second teachers research stage were the following:

1. Determine whether listening to music is less important when implemented with a digital tool. 
2. Determine the importance of digital competences.

3. Determine the impact of digital tools on the education process.

\section{METHODOLOGY}

\section{PARTICIPANTS}

The research was conducted in two stages, during January and February 2021 in four elementary schools in Osijek-Baranya County and Vukovar-Srijem County. The research encompassed 675 students of general education schools from fifth to eighth grade and their three Music Culture teachers, one of which is employed in two general education schools due to lesson time shortage. The participants were informed of the aim of the research, guaranteed anonymity and were asked to answer the questions in both stages truthfully and precisely, all in accordance with ethic principles.

\section{RESEARCH INSTRUMENT AND PROCEDURE}

Two questionnaires were made for the general education students and two for the Music Culture teachers for the purposes of the research. The first part of the students' questionnaires contains questions pertaining to the sociodemographic attributes of the students (location of school, sex, grade). The student sample structure is shown in Table 1. The second part of the questionnaire (for students and teachers) contains different questions pertaining to listening to music in Music Culture, before and after using Kahoot!

Table 1. Student sample structure $(\mathrm{N}=675)$

\begin{tabular}{ccc}
\hline Attribute & f & \% \\
\hline sex & & \\
male & 323 & $47.85 \%$ \\
female & 352 & $52.15 \%$ \\
grade & & \\
5th & 134 & $19.85 \%$ \\
6th & 167 & $24.74 \%$ \\
7 th & 173 & $25.63 \%$ \\
8th & 201 & $29.78 \%$ \\
School location & & \\
Urban & 366 & $54.22 \%$ \\
Suburban & 250 & $37.04 \%$ \\
Village & 59 & $8.74 \%$ \\
Total & 675 & \\
\hline
\end{tabular}

The questionnaire intended for Music Culture teachers contained, just as the students' questionnaire, questions pertaining to their sociodemographic 
attributes (sex, years of work experience, education level and school location). The teacher sample structure is shown in Table 2. The second part contained questions on equipment present in their usual daily classrooms, usage of digital tools, the way they implement listening to music, expressing their attitude towards traditional listening and listening through Kahoot! before the research and afterwards. Before the research itself, it was also established that all classrooms are appropriately equipped (computer, Internet connection, projector, projection screen, speakers, tablets for students were present) and appropriate conditions for stage one and two were met.

Table 2. Teacher sample structure $(\mathrm{N}=3)$

\begin{tabular}{ccc}
\hline Attribute & f & $\mathbf{\%}$ \\
\hline $\begin{array}{c}\text { sex } \\
\text { female }\end{array}$ & 3 & $100 \%$ \\
Years of work & & \\
experience & & \\
$0-10$ & 1 & $33.33 \%$ \\
$21-30$ & 2 & $66.67 \%$ \\
Professional & & \\
qualification & & \\
University degree & & \\
& 3 & $100 \%$ \\
School location & & \\
Urban & 2 & $66.67 \%$ \\
Suburban & 1 & $33.33 \%$ \\
Village & 1 & $33.33 \%$ \\
Total & 3 & \\
\hline
\end{tabular}

The first research stage had students $(\mathrm{N}=675)$ and Music Culture teachers $(\mathrm{N}=3)$ filling out questionnaires at the end of January 2021. The students' questionnaire had six closed-ended questions with two or more answer alternatives. The Music Culture teachers' questionnaire had 18 closed-ended questions with two or more answer alternatives, and questions to ascertain attitudes on the importance of listening to music constructed in accordance with a Likert scale ( 1 - cannot determine, 2 - do not agree, 3 - agree, 4 - mostly agree and 5 - completely agree).

The second research stage took place in February 2021. Before beginning, a meeting with the Music Culture teachers was held to choose lesson units for their classes (musical instruments, musical types, elements and forms, singing voices, musical and stylistic periods, and traditional music of Croatia and other countries). They were also provided with detailed information on Kahoot! to enable a more fluid progress of the second research stage. As part of the 
curricular reform Škola za život ("School for Life"), students were provided with tablets at the beginning of the school year, so there was no need for them to bring their personal devices to be able to use Kahoot! The second stage lasted three weeks, i. e. three lesson periods, two of which entailed listening to music with the use of the digital tool, and the last week entailed measuring attitudes of students and teachers on listening to music as part of Music Culture lessons after using the digital tool.

\section{RESULTS AND DISCUSSION}

The question asking students to determine whether they enjoy listening to music in the first stage had $87 \%$ positive and $13 \%$ negative student answers. The result can be used to positively affirm the first hypothesis that students do enjoy listening to music, and build upon the research of Šuletić Begić (2013) claiming that $100 \%$ of students replied positively to enjoying listening to music. Therefore, the conclusion is reached that students enjoy listening to music, though the question whether they prefer listening to music they encounter in Music Culture education or the music they choose themselves remains.

The answers to the question whether students listen to the music they've encountered in Music Culture education at home are devastating. 94\% of students sadly do not listen to that music at home, and only $6 \%$ do value musical arts and listen to it at home. This result affirms our second hypothesis. Gaggiolo and Lamont (2003, as cited in Vidulin, 2013), and Hargreaves, Marshall and Tarrant (2003, as cited in Vidulin, 2013) show in their research that the younger population prefers easily accessible and readily understandable music. Such music doesn't require musical knowledge or much concentration while listening. This attitude leads us to the conclusion that youths don't want to listen to artistic music, but music that speaks to them directly; such music leads them to ways of coping with feelings, goals to be coveted and descriptions of ideal appearances. Škojo, Radočaj-Jerković and Milinović (2016) explain that modern means of production and audio reproduction contribute to popularising such music, and enable its mass distribution, ubiquitousness and easy accessibility to all.

We still should not lose hope. Šulentić Begić and Begić (2013) carried out research in the I Gymnasium in Osijek, the results of which show that students don't reject artistic music, even though most of them do not listen to that type of music in their free time. Of all the participants, $71.56 \%$ had the attitude of enjoying listening to artistic music during their Music education, but it is usually not their first choice.

The third hypothesis is affirmed by the results showing that the Music Culture teachers $(\mathrm{N}=3)$ use digital tools in each lesson or once every two weeks. If they answered affirmatively, the questionnaire required them to list the digital 
tools they had already used for teaching. The teachers listed the following: Wizer, Wordwall, Kahoot!, Edpuzzle, Mentimeter, Lino it and Canva.

An analysis of the list of tools they'd already used shows it is not short, the teachers have high computer competences, and they are mostly prepared for the challenges of teaching in the 21 st century.

The answers to the questionnaire assert that the teachers use listening to music in a standard methodological way, meaning they prepare assignments for active listening after carefully selected representative music pieces. The assignments prepare the students for active listening to music, and usually require the students to recognise and determine the following musical elements: performers, tempo, dynamic, metre, texture, melody attributes, timbre, type of composition, rhythm or some other parameters of the piece. The teachers were also asked which teaching aids they used for listening to music. The answers shown in Graph 1 depict a very positive result because the teachers don't use just one source, but usually combine a number of them to make sure their lesson, and listening to music, is more interesting to the students.

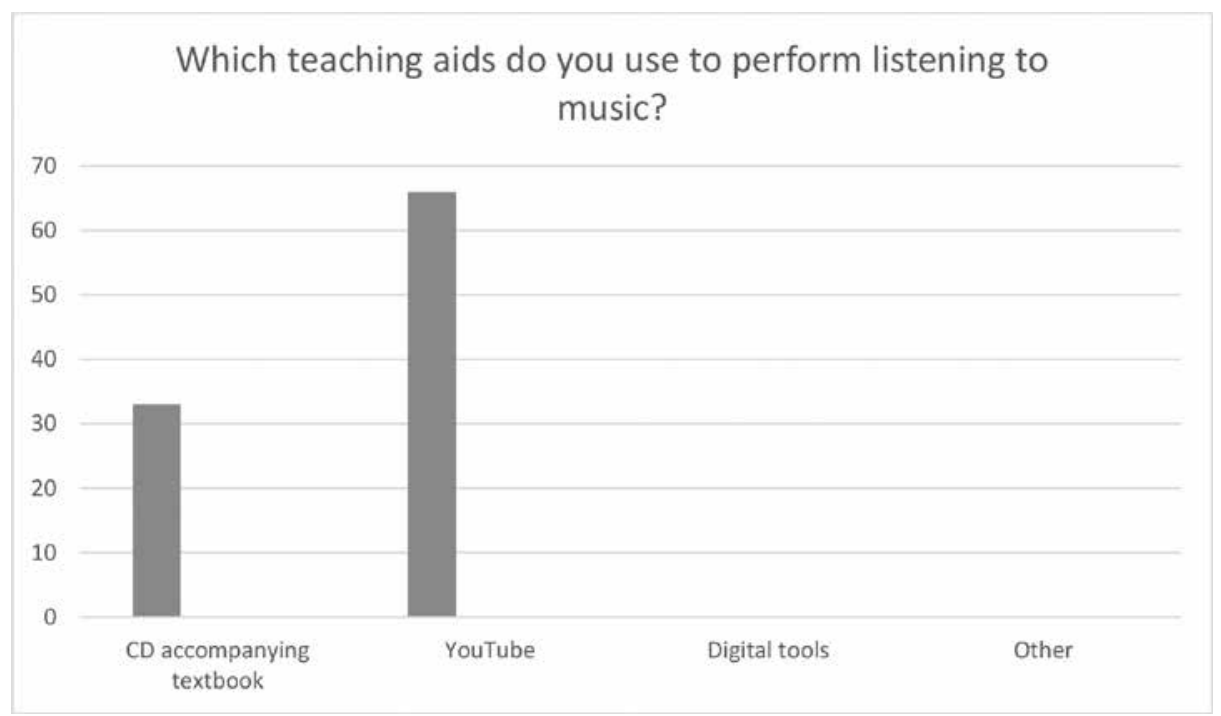

Graph 1. Using teaching aids

In the question designed according to a Likert scale, the teachers expressed their attitude on the importance of listening to music. They completely agree $(100 \%)$ with the following statements:

1. Listening to music is the most important part of Music Culture education.

2. Listening to music is fundamental to all other areas of Music Culture education. 
3. Listening to music should be active and accompanied by clear instructions so students may know which musical elements they should focus on.

4. It is important to direct students to active listening at the earliest possible school age.

5. Passive listening should be avoided as a method of listening.

6. Listening to different types of music excites students towards understanding and multiculturalism.

7. Listening to music teaches students to evaluate music.

These attitudes affirm the hypothesis that teachers consider listening to music one of the most important parts of Music Culture education. The remaining statements that do not have an agreement rate of $100 \%$ are shown in Table 3 below.

Table 3. Results of the remaining attitudes of teachers that do not have a $100 \%$ agreement rate

\begin{tabular}{llll}
\hline Statements & $\begin{array}{l}\text { Completely } \\
\text { agree (f) }\end{array}$ & $\begin{array}{l}\text { Mostly agree } \\
\text { (f) }\end{array}$ & Agree (f) \\
\hline Students enjoy listening to music & 1 & 1 & 1 \\
$\begin{array}{l}\text { Students gain knowledge on elements } \\
\text { of musical expression by listening to } \\
\text { music }\end{array}$ & 2 & 1 & \\
$\begin{array}{l}\text { Listening to music teaches students } \\
\text { how to understand music }\end{array}$ & 2 & 1 & \\
Total & 3 & & \\
\hline
\end{tabular}

An important part of the first stage is the result showing total (100\%) affirmation of the seventh hypothesis about teachers educating themselves on digital tools independently. Thanks to publishers and various projects in Croatia, teachers now have the opportunity to take part in different on-line courses in Croatia and internationally that provide them with the possibility of learning about novel teaching tools and available digital tools. The greater part of digital tools is sadly still available only in English, which means that knowledge of English is of paramount importance for their use. Apart from on-line courses, teachers have the opportunity to learn proper use of digital tools in education from good practice examples or their peers while attending county or state assemblies, which is sadly still a lacking procedure. 
The preparation of a multimedia project for education is a highly complex task that requires team work of a slew of experts - from experts on the subject matter (professors, teachers, instructors...), to instructional designers whose role is to adapt traditional teaching methods to a new medium while taking all of its advantages and disadvantages into account, to development experts of various profiles (graphic designers, tool experts, developers, VA team etc.). However, developing technology and tools has taken a direction of simplifying their use so that they may be accessible to an even broader circle in education, regardless of their knowledge of computers. (Matasić \& Dumić, 2012, p. 145)

The second research stage begins with the use of Kahoot! in lessons during two weeks, i. e. in two different units during two classes. The final phase of the second research stage entailed the students and teachers filling out the second questionnaire after this way of listening to music in class. The results pertain to the attitudes of students and teachers on listening to music after using a digital tool.

The question whether listening to music in Music Culture education was more interesting with Kahoot! was answered affirmatively by $96.59 \%(\mathrm{~N}=625)$ of students, while $3.41 \%(\mathrm{~N}=23)$ of students see it as not interesting. Similar results were recorded for questions pertaining to the motivation of students in regards to Music Culture education. Kahoot! motivated them to listen to music more actively, take part in lessons more actively and introduced positive competitiveness into the education process. The positive results of the second stage affirm our fifth hypothesis stating that students take part in lessons more actively when using digital tools. These results and the hypothesis are also affirmed by the research of Nikolić, Havzić, Narandžić, Dakić and Janković (2020) on the integration of Kahoot! in higher education. Their analysis shows that $78 \%$ of university students were motivated to participate more actively in class with the use of Kahoot! It also shows the impact on students' motivation and competitiveness.

The most notable question in the questionnaire for teachers in the second stage is the open-ended question: Which influence on the activity of students in Music Culture lessons do you perceive after using digital tools? The teachers have given mostly positive answers, which somewhat affirms our sixth hypothesis ("Students listen to music more actively when using digital tools"). They list the following answers:

- The influence of the digital tool is very positive and apparent even after the first lesson.

- Students participate more actively.

- Students absorb matter more easily, regardless of the chosen type of music.

- Students listen to music more actively.

- Students find Music Culture lessons more interesting with Kahoot! 
- Students have less issues answering questions if they have multiple alternative answers (determining musical elements, parts of compositions or performing ensembles).

- Students and teachers alike develop digital competences.

But the disadvantages of the digital tool should not be disregarded. The teachers understand that using Kahoot! for listening to music may lead students to passive listening because they focus on their response time and the scorecards at the end of the activity, instead of focusing only on the music. Passive listening may be avoided while using a digital tool if the teacher is well prepared and provides students with clear instructions before the listening activity.

Various research has shown that a piece should be listened to multiple times for it to be completely perceived and for all the musical elements to be recognised. Gilliland and Moore (Rojko 2012) came to the realisation that repetitive listening of classic works leads to students enjoying them more, as opposed to popular music. Vidulin-Orbanić (2002) mentions that repeated listening in education may lead to recognising hidden details in the piece usually not noticeable during the first listening. Repeated listening may also be implemented with Kahoot! While designing questions, there is an option to select the length of the musical example, and the chosen part of the composition can be listened to repeatedly combined with multiple different questions.

The last question in the questionnaire, I believe Kahoot! should be used more often for listening to music in Music Culture education, was answered affirmatively by students and teachers. $94.22 \%(\mathrm{~N}=636)$ of students answer affirmatively, only $5.77 \%(\mathrm{~N}=39)$ do not want to see the digital tool used more often. All of the Music Culture teachers answer affirmatively (result percentages shown in Graph 2). Dobrota (2015, as cited in Rudolph et. al., 2005) sees modern technology as having a great application in musical education. The research she mentions shows students becoming more active in the education process also become more self-assured, effective in their learning and better motivated to continue learning. She also points out that the use of the same technology in musical education should be thoroughly methodically planned because its excessive use will not have a considerable influence on the musical development of a child.

Considering the methods of monitoring and evaluating students' results, Kahoot! fosters competitiveness in students and encompasses real-time play. That is why we recommend using the tool as part of motivational lesson segments. (Tomaš, 2018, p. 26). 


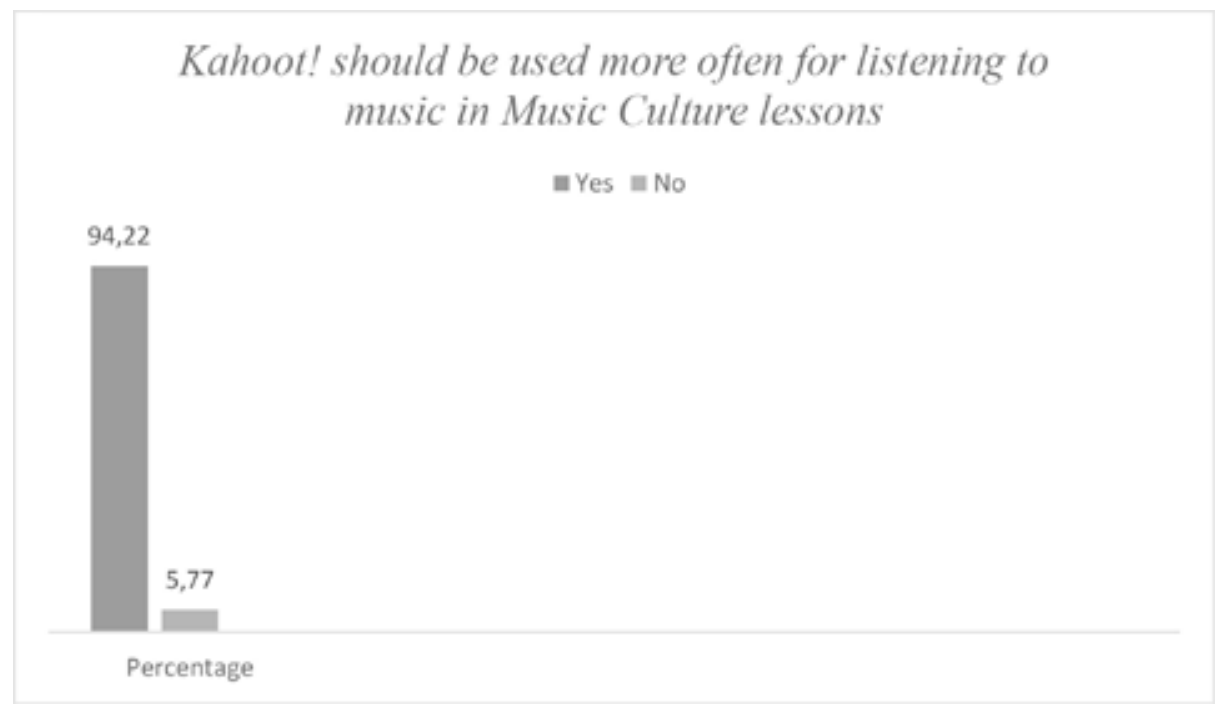

Graph 2. Students' attitude results regarding the final question of the second questionnaire

\section{CONCLUSION}

Changes are necessary in teaching younger and more digitally savvy generations, and these changes create the opportunity to implement new technology, such as different digital tools. Those digital tools may enrich Music Culture and other education, as well as make it more interactive. This would then fulfil students' needs for a more interesting and more digital education. At the same time, it poses new questions, opens new possibilities and creates opportunities for further advancement of teaching methodology.

This research shows students enjoy listening to music, which is why we should strive to make the examples they listen to are of high quality and interesting, so their love for music and possible motivation for future musical endeavours may develop. This research may be used as a starting point for further research into motivation levels and real influence of digital tools on the improvement of students' results and a more active listening to music.

This paper also aims to emphasise the need for teachers to undergo various continuous professional training and acquiring of competences regarding the use of digital tools. Teachers strive to abandon traditional ways of learning and teaching, but a lack of professional education makes it difficult to achieve. Just like students, teachers should have the opportunity for lifelong learning to prepare them for the coming challenges of the modern school.

Nevertheless, digitalisation should be applied with caution, because teachers and the spoken word have no replacement in the classroom. Excessive 
use of digital tools in education may lead to the negative result of teachers losing their position in the education process. That is why digital tools and similar aids should remain just that - aids for teachers to break the monotony of the classroom, help students approach the subject matter, foster their curiosity and have more diverse lessons, all for the sole purpose of enriching the knowledge and facilitating the progress of students.

Teaching strategies and methods depend mostly on the teacher, and therein stem the ways students learn. Fast and rapid growth of technology are features of the 21st century, and the use of technology is more and more prevalent in education which, in turn, is becoming more modern. That is why today's successful and effective teacher is one who acknowledges the challenges of modern education, implements them in a student-appropriate way, and continues to grow and improve in accordance with them. (Tomaš, 2018, p. 115)

\section{REFERENCES}

Bognar, L., Matijević, M. (2005). Didaktika. Školska knjiga.

Dobrota, S. (2016). Glazbena nastava i nastavna tehnologija. Zbornik radova Filozofskog fakulteta u Splitu, (6-7), 6-23. https://hrcak.srce.hr/154573

Dobrota, S. (2016). Stavovi studenata prema umjetničkoj glazbi i glazbenoj nastavi. Školski vjesnik, 65 (Tematski broj), 33-47. https://hrcak.srce.hr/160074

Groznik, B. (2021). nastava uz pomoć platforme za učenje Kahoot. Varaždinski učitelj, 4 (6), 190-204. https://hrcak.srce.hr/254553

Lasić-Lazić, J., Špiranec, S. i Banek Zorica, M. (2012). Izgubljeni u novim obrazovnim okruženjima - pronađeni u informacijskom opismenjavanju. Medijska istraživanja. 18 (1), 125-142. https://hrcak.srce.hr/85384

Matasić, I. i Dumić, S. (2012). Multimedijske tehnologije u obrazovanju. Medijska istraživanja, 18 (1), 143-151. https://hrcak.srce.hr/85389

Matijević, M., Topolovčan, T. (2017). Multimedijska didaktika. Školska knjiga.

Milinović, M. (2018). Prisutnost glazbe na društvenim mrežama među gimnazijalcima. U B. Jerković i T. Škojo (ur.), 2. Međunarodni znanstveni i umjetnički simpozij o pedagogiji u umjetnosti - Komunikacija i interakcija umjetnosti i pedagogije. (str. 280-296). Umjetnička akademija u Osijeku.

Mlinarević, V. Borić, E. (2007). Stručni razvoj učitelja kao pretpostavka suvremene škole. U V. Previšić, N. Šoljan i N. Hrvatić (ur.), Prvi kongres pedagoga Hrvatske Pedagogije: prema cjeloživotnom obrazovanju i društvu znanja. (str. 421-431). Hrvatsko pedagogijsko društvo.

Ministarstvo znanosti i obrazovanja (2010). Nacionalni okvirni kurikulum za predškolski odgoj $i$ obrazovanje te opće obvezno i srednjoškolsko obrazovanje. Republika Hrvatska, Ministarstvo znanosti i obrazovanja. http://mzos.hr/datoteke/ Nacionalni_okvirni_kurikulum.pdf 
Ministarstvo znanosti i obrazovanja (2006). Nastavni plan i program za osnovnu školu. Republika Hrvatska, Ministarstvo znanosti i obrazovanja. https://narodne-novine. nn.hr/clanci/sluzbeni/2006_09_102_2319.html

Negulić, T. (2015). Kahoot - sustav za odgovaranje $i$ kvizove. Hrvatska akademska i istraživačka mreža - CARNET. https://e-laboratorij.carnet.hr/ kahoot-game-based-sustav-za-odgovaranje-i-kvizove/

Nikolić, D. Havzi, S. Narandžić, D. Dakić, D. i Janković, A. (2020). Inovativne metode učenja u visokom obrazovanju integracijom softverskog alata Kahoot!. U V. Katić (ur.), 26. skup Trendovi razvoja: Inovacije u modernom obrazovanju. (str. 1-4). Fakultet tehničkih nauka Univerziteta u Novom Sadu. http:/www.trend.uns.ac.rs/ stskup/trend_2020/radovi/T1.3/T1.3-13.pdf

Nikolić, D. Lolić, T. Havzi, S. Spasojević, I. Stefanović, D. (2021). Primena softverskih alata baziranih na igri u online okruženju učenja. U V. Katić (ur.), 27. Skup trendovi razvoja: On-line nastava na univerzitetima. (str. 91-94). Fakultet tehničkih nauka Univerziteta u Novom Sadu. http://www.trend.uns.ac.rs/stskup/trend_2021/ radovi/T1.1/T1.1-19.pdf

Novosel, D. (2017). Didaktičko oblikovanje multimedijskog udžbenika u nastavi Glazbene kulture. [doktorska disertacija, Sveučilište u Zagrebu]. Repozitorij Filozofskog fakulteta u Zagrebu. https://core.ac.uk/download/pdf/299373325.pdf Poljak, V. (1990). Didaktika. Školska knjiga.

Puževski, V. (2002). Škola otvorenih vrata. Naklada Slap.

Rojko, P. (2012). Metodika nastave glazbe: teorijsko-tematski aspekti. Sveučilište J. J. Strossmayera, Pedagoški fakultet Osijek.

Sims, Wendy L. (1990). Sound Approaches to Elementary Music Listening. Music Educators Journal. 77(4), 38-42. https://doi.org/10.2307/3397880

Svalina, V. (2015). Kurikulum nastave glazbene kulture i kompetencije učitelja za poučavanje glazbe. Sveučilište J. J. Strossmayera u Osijeku, Fakultet za odgojne i obrazovne znanosti.

Škojo, T., Radočaj-Jerković, A., Milinović, M. (2016). Utjecaj zborskoga pjevanja na razvoj glazbenih preferencija djece predškolske dobi. U R. Jukić, K. Bogatić, S. Gazibara, S. Pejaković, S. Simel, V. Nagy, V. Aniko Campbell-Barr (ur.), Globalne i lokalne perspektive pedagogije. (str. 59-72). Filozofski fakultet u Osijeku.

Šulentić Begić, J. (2012). Otvoreni model glazbene nastave u praksi osnovne škole (Slušanje glazbe i pjevanje). Metodički priručnik za učitelje i studente glazbene kulture, glazbene pedagogije i primarnog obrazovanja. Učiteljski fakultet.

Šulentić Begić, J. i Birtić, V. (2012). Otvoreni model nastave glazbene kulture u primarnom obrazovanju u nekim osječkim osnovnim školama. Tonovi, 60, 72-84. https://www.bib.irb.hr/607445

Šulentić Begić, J., Begić, A. (2013). Glazbene preferencije učenika I. gimnazije u Osijeku. U M. Brekalo, I. Žužul (ur.), Kultura, društvo, identitet-europski realiteti. (str- 844-861). Sveučilište J. J. Strossmayera u Osijeku, Odjel za kulturologiju. 
Tomaš, S. (2018). Digitalne tehnologije kao potpora praćenju i vrednovanju. Hrvatska akademska $\mathrm{i}$ istraživačka mreža - CARNET.

https://pilot.e-skole.hr/wp-content/uploads/2018/03/Prirucnik_Digitalne-tehnologijekao-potpora-pracenju-i-vrednovanju.pdf

Vidulin, S. (2013). Playing Instrument in the Music Culture Teaching: an Opportunity of Active Perception and Understanding of Music. Glasbeno-pedagoški zbornik, 19, 23-39. https://www.bib.irb.hr/686737? $\mathrm{rad}=686737$

Vidulin, S. i Martinović, V. (2015). Umjetnička glazba i oblikovanje kulturnoga identiteta učenika. Školski vjesnik, 64 (4), 573-588. https://hrcak.srce.hr/153129

Vidulin-Orbanić, S. (2002). Pristup glazbi u prvim školskim godinama. Tonovi, 40 (1), 49-55. https://www.bib.irb.hr/439636

Vidulin-Orbanić, S. i Terzić, V. (2011). Polazište i pristup pjevanju u općeobrazovnoj školi. Metodički ogledi, 18 (2), 137-156. https://hrcak.srce.hr/82321

Zrilić, S. i Marin, K. (2019). Kompetencije u suvremenoj školi - potrebe prakse iz perspektive učitelja. Školski vjesnik, 68. (2.), 389-400. https://hrcak.srce.hr/234953 